\title{
Holocene vegetation, climate and fire dynamics in the Serra dos Órgãos, Rio de Janeiro State, southeastern Brazil
}

\author{
MARIA CAROLINA G. DE O. PORTES ${ }^{1,2^{*}}$, HERMANN BEHLING ${ }^{2}$, \\ VINCENT MONTADE ${ }^{3,2}$ and HUGH D. SAFFORD ${ }^{4,5}$ \\ ${ }^{1}$ NGI Curitiba, Instituto Chico Mendes de Conservação de Biodiversidade, Brazil; e-mail: mcportes@gmail.com \\ ${ }^{2}$ Department of Palynology and Climate Dynamics, University of Goettingen, Germany \\ ${ }^{3}$ Institut des Sciences de l'Evolution de Montpellier, Université de Montpellier, France \\ ${ }^{4}$ USDA Forest Service Pacific Southwest Region, USA \\ ${ }^{5}$ Department of Environmental Science and Policy, University of California, USA
}

Received 1 September 2020; accepted for publication 11 December 2020

\begin{abstract}
We analysed pollen and macro-charcoal from a sediment core representing the last 9840 cal yr BP, collected at $2003 \mathrm{~m}$ a.s.l. in a patch of upper montane Atlantic Rain Forest (UMARF) embedded in a campos de altitude (high-elevation grassland) matrix in the Serra dos Órgãos National Park, southeastern Brazil. From 9840 to 4480 cal yr BP, campos de altitude (CDA) was the dominant vegetation at the site, indicating that the climate was relatively cool and dry. However, pollen data document that UMARF was near the core site throughout the recorded Holocene. Relatively frequent high-magnitude fires occurred during the Early Holocene but became rarer in the Mid-Holocene after $4480 \mathrm{cal}$ yr BP, when the climate became wetter. In the Mid-Holocene, UMARF and tree fern taxa became slightly more frequent at the site, but CDA vegetation continued to dominate most of the high-mountain landscape. A climatic change to wetter and warmer conditions during the last $1350 \mathrm{cal} \mathrm{yr} \mathrm{BP}$ is evidenced by an increase in UMARF and even lowland forest taxa in our core, as well as the near complete absence of fire after this date.
\end{abstract}

KEYWORDS: southeastern Brazil, Holocene, campos de altitude (high-elevation grassland), upper montane Atlantic Rain Forest, climate and fire history

\section{INTRODUCTION}

The Brazilian coastal highlands (Serra do Mar) extend for $\sim 1000 \mathrm{~km}$ along the southeastern Brazilian coastline from the state of Santa Catarina $\left(26^{\circ} \mathrm{S}\right)$ to the north of Rio de Janeiro State $\left(21^{\circ} \mathrm{S}\right)$ in the Atlantic Forest domain. The Atlantic Forest is one of the world's great tropical forest biomes, and once covered around 130 million ha of coastal and eastern Brazil, stretching $\sim 4000 \mathrm{~km}$ from $3^{\circ} \mathrm{N}$ latitude to almost $34^{\circ} \mathrm{S}$ (Ribeiro et al., 2009; Fundação SOS Mata Atlantica/INPE, 2017). Due to the variability of environmental

\footnotetext{
Corresponding author
}

conditions (geomorphology/topography, geology, climate, soils, ecosystems) together with a large elevational range, the Atlantic Forest is one of the most diverse biomes in the world and is considered among the most important and most imperilled biodiversity hotspots on earth (Myers et al., 2000). Before European settlement, the Serra do Mar was clothed in dense rainforest for much of its length, with drier cerrado (Brazilian savanna) formations inland, and elfin "cloud forests" and orographic grasslands (campos de altitude) at higher elevations, mostly above $1500-1800 \mathrm{~m}$ a.s.l. (Hueck, 1966; Dean, 1995; Câmara, 2003). 
At the highest elevations, cloud forests (here referred to as "upper montane Atlantic Rain Forest", or UMARF) tend to occupy topographic concavities and other protected sites such as valleys and mild slopes, and campos de altitude (CDA) are more common on hilltops, plains and convex slopes, or where waterlogging occurs (Safford, 1999a).

Climatic changes during the late Quaternary greatly influenced the modern vegetation distribution. Present-day CDA is a vestigial vegetation type from colder and drier climates which reached its widest distribution during the Last Glacial and in particular the Last Glacial Maximum (25,000-17,000 yr BP), when forest vegetation was nearly completely absent in the higher mountains (Behling, 1997b; Behling and Safford, 2010). UMARF expansion began during the Late Glacial, indicating a shift to moister conditions (Behling, 1997b; Ledru et al., 2005; Ledru et al. 2009; Behling and Safford, 2010; Veríssimo et al., 2012). A further increase in both temperature and precipitation in the Early to Mid-Holocene allowed the expansion of the Atlantic Rain Forest to higher elevations, markedly reducing the area occupied by CDA (Behling and Safford, 2010). Displacement of the Intertropical Convergence Zone (ITCZ) over northeastern Brazil might explain the Younger Dryas (YD) warming (second part of the YD period) documented in eastern Brazil, in contrast to the YD cooling in the Northern Hemisphere (Behling and Safford, 2010). A palaeoecological study carried out by Behling and Safford (2010) at $2130 \mathrm{~m}$ elevation in the Serra dos Órgãos (SDO core; Fig. 1c) recorded widespread CDA vegetation and drier climatic conditions until $\sim 5600 \mathrm{cal}$ yr BP. Thereafter a trend

a)

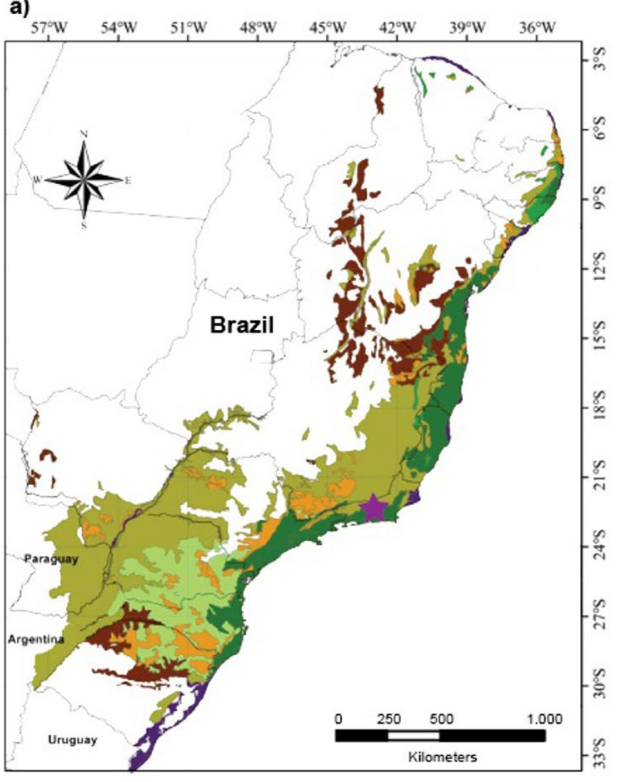

c)

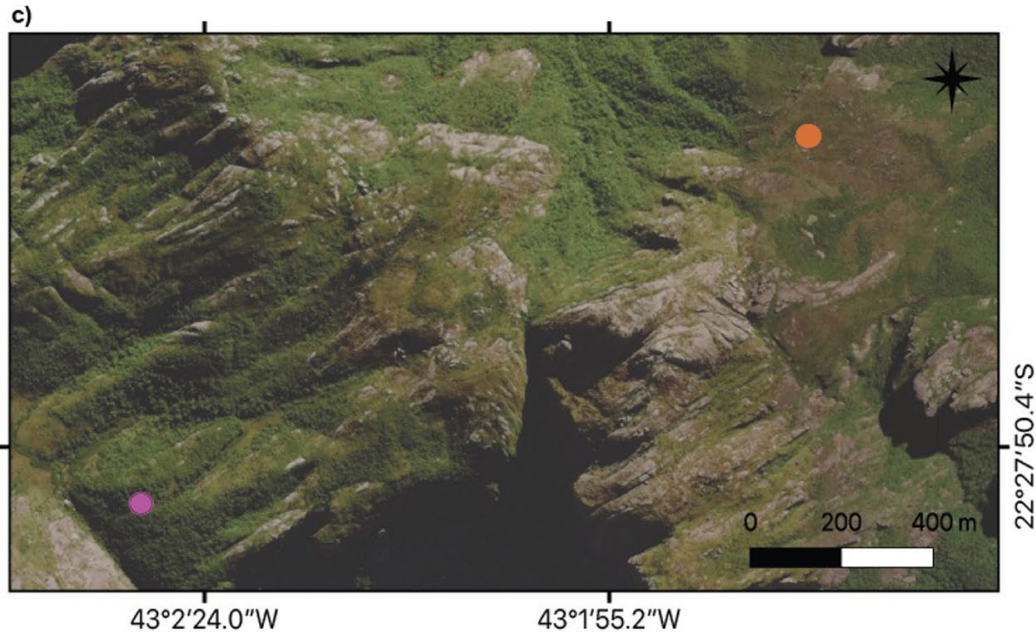

b)
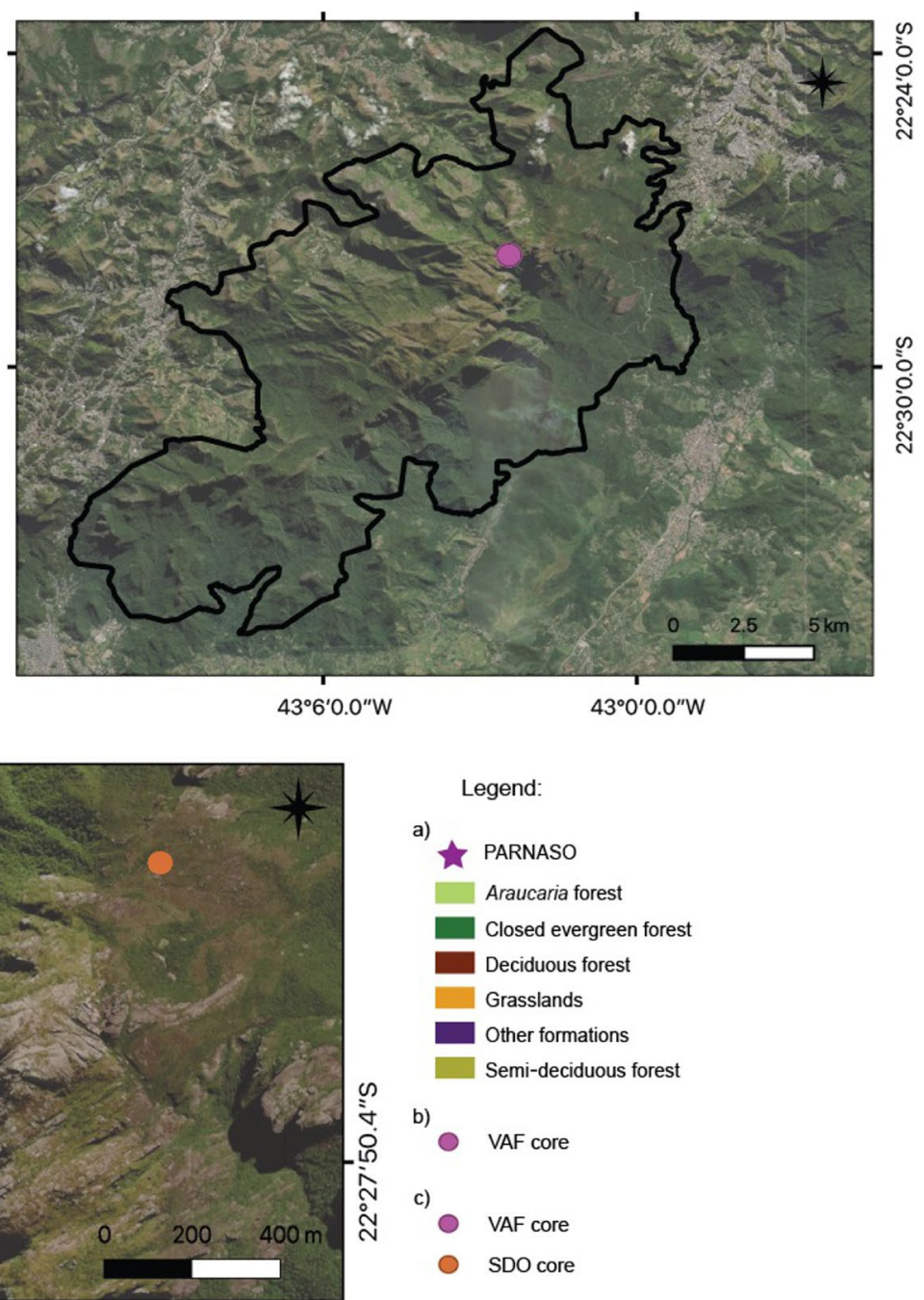

Fig. 1. Location of PARNASO and Vale das Antas Forest (VAF) core. (a) location of PARNASO (adapted from Fundação SOS Mata Atlântica/ INPE, 2017), (b) location of VAF core in PARNASO, and (c) distance and vegetation type of VAF core (in UMARF) and SDO core (in CDA) from Behling and Safford (2010) 
toward warmer and wetter conditions resulted in expansion of montane forest and contraction of campos. The last $\sim 1000$ years were the wettest period during the entire Holocene (Behling and Safford, 2010).

Centuries of exploitation by humans reduced the Atlantic Forest to a patchwork of small fragments in a natural or semi-natural state, covering today only about $10 \%$ of its pre-Columbian area (Fundação SOS Mata Atlantica/ INPE, 2017). While more intense occupation and deforestation occurred after European colonization, starting at $\sim 1500 \mathrm{AD}$, the history of human presence along the Brazilian coast started with the migration of Amerindians from the north, arriving in southeastern Brazil about 10,000 years ago (Figuti et al., 2004). Although mostly settled along the coast, these populations also occupied inland forests by $\sim 1800$ yr BP (Noelli, 2008). Evidence is strong that Amerindian practices of land use had important impacts on forest structure and composition before the arrival of Europeans (Portes et al., 2018). The first Portuguese settlements were established mainly in Rio de Janeiro State, beginning a period of more intense exploitation of the forest. Today, the southeast is the most populated region of Brazil, but ironically it supports some of the most important remnants of the Atlantic Forest, due to the steep topography and complex relief of montane areas in the region.

Most of the large forest remnants in southeastern Brazil are found in protected areas. One of the most important is Serra dos Órgãos National Park (PARNASO). Located in the northernmost part of the Serra do Mar, PARNASO protects montane rainforest stands and an important complex of UMARF and CDA on a high plateau that supports many rare and endangered species, from epiphytes and bamboos to large animals such as jaguars (Martinelli and Bandeira, 1989; see also the Brazilian red books for flora and flora: Martinelli and Moraes, 2013 and ICMBio, 2018). As the climate becomes warmer and wetter, upward migration is expected and the reduction of habitat for high-mountain taxa is a strong possibility (Rull et al., 2009; VegasVilarúbia et al., 2011). Understanding the temporal relationships between climate and vegetation is essential for conservation in the face of climate change, and palaeoecological studies can help to reveal which species and ecosystems may need human intervention to persist (Behling and Pillar, 2007; Overbeck et al., 2015; Barnosky et al., 2017). Although the Brazilian highlands have been the object of palaeoecological investigations for more than two decades (e.g., Behling 1995, 1997a,b, 2007; Scheel-Ybert, 2001; Ledru et al., 2005; Behling et al., 2007, 2020; Behling and Safford, 2010; Veríssimo et al., 2012; Raczka et al., 2013; Portes et al., 2018), much more remains to be learned about how montane vegetation in this region is influenced by climate, fire and human impacts over the long term.

Here we report results from a multi-proxy study that analysed temporal vegetation dynamics in a forest patch currently occupied by UMARF and surrounded by CDA vegetation, located near the SDO core sampled by Behling and Safford (2010). Overall, our goal was to better understand temporal dynamics between forest and grassland vegetation in a highly heterogeneous landscape characterized by high biodiversity and high species turnover. Specifically, we wanted to determine (1) how climatic change and fire interacted at this montane forest site to influence vegetation composition and dynamics during the Holocene, and (2) how Holocene vegetation dynamics differed in this forest patch as compared to the CDA vegetation sampled in the nearby SDO core (Behling and Safford 2010).

\section{ENVIRONMENTAL SETTINGS}

The study site (2003 m a.s.l., $22^{\circ} 27^{\prime} 53.49^{\prime \prime} \mathrm{S}$, $\left.43^{\circ} 2^{\prime} 27.04^{\prime \prime} \mathrm{W}\right)$ is located in Serra dos Órgãos National Park (PARNASO), Rio de Janeiro State, southeastern Brazil (Fig. 1). The southeast-facing site is a 2.2 ha patch of upper montane Atlantic Rain Forest (UMARF) bordered by campos de altitude (CDA) in the Serra dos Órgãos, a subrange of the Serra do Mar (Brazilian coastal highlands), $\sim 90 \mathrm{~km}$ from the Atlantic Ocean. The geologic substrate in the study area is Upper Proterozoic granite and granitoid gneiss, uplifted to its present elevation by Cenozoic tectonism associated with widening of the Atlantic Ocean (Riccomini et al., 1989). The Serra dos Órgãos follows a largely NE-SW orientation parallel to the coast. Soils at the study site are generally shallow, poorly developed, acidic and highly organic, with high amounts of litter (Falkenberg and Voltolini, 1995). 
In the region the climate is controlled mostly by the South Atlantic Convergence Zone (SACZ), with most precipitation falling between November and April (Safford, 1999a; Vuille et al., 2012). The climate for the region generally has been defined as mesothermic, with mild and wet summers and moderate winters without a welldefined dry season (Nimer, 1977; ICMBio, 2008). The nearest long-term meteorological station is at Teresópolis $\left(22^{\circ} 25.980^{\prime} \mathrm{S}, 42^{\circ} 58.980^{\prime} \mathrm{W}\right)$ at $1100 \mathrm{~m}$ a.s.l., where mean annual temperature is $17.6^{\circ} \mathrm{C}$ (July mean $=8.6^{\circ} \mathrm{C}$, February mean $=27.2^{\circ} \mathrm{C}$ ) and mean annual average precipitation is $1800 \mathrm{~mm}$ (Hijmans et al., 2005). Our field site is $900 \mathrm{~m}$ higher and there is considerable orographic enhancement of precipitation, resulting in a winter without a true dry season. PARNASO installed temperature data loggers near the study site in September 2012. Between September 17, 2012, and February 2, 2014, the mean overall temperature was $12.7^{\circ} \mathrm{C}$, the maximum was $25.6^{\circ} \mathrm{C}$ and the minimum was $1^{\circ} \mathrm{C}$ (C. Cronemberger, PARNASO, pers. comm.). Temperatures in the nearby CDA in the Vale das Antas (slightly below our study site, in the valley bottom) showed a similar mean temperature $\left(12.5^{\circ} \mathrm{C}\right)$ but the temperatures were more extreme due to the lack of trees and the valley bottom position $\left(\max =27^{\circ} \mathrm{C}, \min =-5 \cdot 2^{\circ} \mathrm{C}\right)$. Safford (unpub. data) also measured winter temperatures in the Vale das Antas campos: in July 1997 a minimum of $-9.8^{\circ} \mathrm{C}$ was measured, which is the lowest temperature recorded for the Serra dos Órgãos. From regressions against elevation, Safford (1999a,b; Behling and Safford, 2010) estimated precipitation at $2000 \mathrm{~m}$ elevation in the Serra dos Órgãos study site to be between 2500 and $3000 \mathrm{~mm}$ annually.

In the Serra dos Órgãos, CDA vegetation occurs above 1800-2000 m elevation, depending on substrate, topography, slope, aspect, and history of disturbance (Safford 1999a). CDA is most common on hilltops and convex slopes, and also dominates poorly drained valley bottoms (Safford, 1999a; see Fig. 1). Below 1800-2000 m elevation UMARF is the dominant vegetation, gradually replacing tall montane forest above $\sim 1500 \mathrm{~m}$ a.s.l., while above these elevations UMRAF becomes more and more restricted to protected sites.

The CDA is dominated by graminoids, in PARNASO especially by the giant bunchgrass Cortaderia modesta, montane bamboo (Chusquea pinifolia) and the large sedge
Machaerina ensifolia. Frequent herb genera include Eryngium (Apiaceae), Paepalanthus, Plantago and Xyris (Behling and Safford, 2010). Many sclerophyllous shrub taxa are found in the CDA, as well as smaller trees, often in some stage of succession toward (after fire or livestock incursion) or away from grassland (longterm lack of disturbance). More open habitats tend to support more woody taxa from Asteraceae (e.g., Baccharis, which is a good indicator of campos vegetation). Certain woody taxa from genera such as Croton and a number of genera from Myrtaceae (Myrceugenia, Gomidesia) and Ericaceae (Gaylussacia) are also more common in campos habitat. However, most woody taxa in the campos are forest taxa and their density is higher near forest borders. The UMARF is formed by twisted and dwarfed trees and shrubs distributed largely in one stratum normally less than $10 \mathrm{~m}$ high. Due to high air humidity and frequent fog, there is high abundance and diversity of epiphytes and mosses on tree trunks and branches, rocks and soil (Falkenberg and Voltolini, 1995; Safford, 1999a; Portes et al., 2001). Important tree genera include Myrsine, Weinmannia, Clethra, Daphnopsis, Roupala, Symplocos, Tibouchina, Ilex, Ocotea and a number of genera from Myrtaceae (Behling and Safford, 2010; Gomes, 2015). Tree ferns of various species are common, as well as epiphytes such as bromeliads and orchids. The grassland-forest ecotone, where scattered trees/open forest cover and understory species co-dominate, is marked by very high habitat heterogeneity. Many herbaceous species from Rubiaceae are especially common in these situations, likewise shrubs of Myrtaceae and Melastomataceae.

Our study site consists of an island of UMARF surrounded by CDA vegetation, located in a protected site facing southeast at $2003 \mathrm{~m}$ a.s.l. (Fig. 1), $1.5 \mathrm{~km}$ from the higherlocated SDO core site at $2130 \mathrm{~m}$ a.s.l. (Behling and Safford, 2010).

\section{MATERIAL AND METHODS}

\section{SEDIMENT CORE SAMPLING AND DATING}

In February 2015, a peat deposit was cored and a core $88 \mathrm{~cm}$ long was collected in an undisturbed area of UMARF on the lower slopes of the Vale das Antas ("Tapir Valley") and herein called VAF (Vale das Antas Forest). From a base of bedrock, the $88 \mathrm{~cm}$-long core was extruded onsite in two sections using a Russian Corer, wrapped in plastic film, and stored under 
$\operatorname{cool}\left(\sim 4^{\circ} \mathrm{C}\right)$ and dark conditions. Six organic bulk sediment samples were collected along the sediment for radiocarbon dating. Two samples were analysed at the Accelerator Mass Spectrometry (AMS) Laboratory at National Taiwan University (NTUAMS), and four samples at the AMS Poznan Radiocarbon Laboratory (LAMS) (Tab. 2). HCl tests on several core samples were negative and excluded the possibility of a carbon reservoir effect. The age-depth model was built with R-package Clam 2.2 (Blaauw, 2010) in R-Studio (R-Studio Team, 2016) using the Southern Hemisphere calibration curve SHCal13.14C and postbomb curve SH 1-2. Calib 7.1 was used for calculating median probability (Stuiver et al., 2019).

\section{PALYNOLOGICAL ANALYSIS}

In total, 44 subsamples $\left(0.25 \mathrm{~cm}^{3}\right)$ in $2 \mathrm{~cm}$ intervals were taken along the core for analysis of palynomorphs. Standard pollen techniques were used to process the samples, applying $40 \%$ hydrofluoric acid (HF) and acetolysis (Faegri and Iversen, 1989). The marker Lycopodium clavatum (20848 \pm 1546 , batch 1031$)$ was added to each subsample to determine the pollen concentration (grains $\mathrm{cm}^{-3}$ ) and pollen accumulation rate (grains $\mathrm{cm}^{-2} \mathrm{yr}^{-1}$ ) (Stockmarr, 1971). The obtained residue was kept in distilled water and mounted on slides with glycerine for palynomorph analysis under a light microscope. A minimum of 300 pollen grains per sample were counted. Pollen and spores were identified based on the Brazil reference collection of the Department of Palynology and Climate Dynamics at the University of Goettingen, and with support of literature and electronic pollen keys (Behling, 1993; Melhem et al., 2003; Neotropical Fossil Pollen Search Tool developed by Dr. Hermann Behling and Dr. Chengyu Weng [unpublished]). Nomenclature is based on Flora do Brasil 2020 (http://floradobrasil.jbjr.gov.br).

Pollen and spore percentages were calculated from the pollen sum, including herbs, shrubs, trees and unknowns, and excluding ferns, mosses, fungal and non-pollen palynomorphs (NPPs). The groups were separated following Behling and Safford (2010) for further comparison: campos de altitude (CDA), upper montane Atlantic Rain Forest (UMARF), other Atlantic Rain Forest (OARF), lowland Atlantic Rain Forest (LARF), ferns (tree ferns and ferns), mosses, fungal spores and NPPs. The pollen diagram was constructed with C2 (Juggins, 2007 ); it portrays the most important taxa based on frequency and dominance. TILIA and TILIAGRAPH were applied to determine pollen assemblage zones based on stratigraphic constrained cluster analysis of the pollen sum by CONISS (Grimm, 1987).

\section{MACRO-CHARCOAL ANALYSIS}

For analysis of the past fire regime and its influence on vegetation, macro-charcoal particles $(>150 \mu \mathrm{m})$ were counted in a total of 176 subsamples of $0.5 \mathrm{~cm}^{3}$ continuously extracted from the core at $0.5 \mathrm{~cm}$ resolution. Samples were prepared following the method of Stevenson and Haberle (2005, adapted from Rhodes, 1998), a procedure that greatly limits particle fragmentation. We added $6 \% \mathrm{H}_{2} \mathrm{O}_{2}$ to remove organic material in the sediment and gently wet-sieved the samples, retaining particles $\geq 150 \mu \mathrm{m}$. Concentrations were determined as particles per $\mathrm{cm}^{3}$. Fire regime characteristics were identified using CharAnalysis software (Higuera, 2009). The data were interpolated to the median temporal resolution (42 years) to obtain the charcoal accumulation rate (CHAR particles $\mathrm{cm}^{-2} \mathrm{yr}^{-1}$ ). A window of 1000-year locally weighted regression was applied to separate background components $\left(\mathrm{C}_{\text {background }}\right)$ and peak components $\left(\mathrm{C}_{\text {peaks }}\right)$ (Higuera et al., 2010). A Gaussian mixture model was used to identify the $\mathrm{C}_{\text {noise }}$ distribution. The $99^{\text {th }}$ percentile of the $\mathrm{C}_{\text {noise }}$ distribution was used to define thresholds. Poisson minimum-count was used to eliminate the peaks from statistically nonsignificant counts. We used a window of 1000 years to estimate the distribution of fire frequencies. Peak magnitude as an estimate of total charcoal deposition per fire event was used to reflect fuel consumption per fire and/or fire size (Higuera et al., 2010; Biagioni et al., 2015).

\section{LOSS ON IGNITION}

To estimate the organic matter and carbonate content in the sediment, $0.5 \mathrm{~cm}^{3}$ subsamples were continuously extracted from the sediment and immediately weighed. The samples were dried at $105^{\circ} \mathrm{C}$ for $24 \mathrm{~h}$ and combusted at $550^{\circ} \mathrm{C}$ during $4 \mathrm{~h}$. Afterwards the samples were dried again and $\mathrm{OM} \%$ was calculated following the method described in Heiri et al. (2001).

\section{RESULTS}

\section{STRATIGRAPHY, CHRONOLOGY AND ACCUMULATION RATE}

The 88 cm-long core consists mostly of black organic material on a rocky subsurface. A detailed description is given in Table 1 .

Six AMS radiocarbon dates were used to construct the age-depth model (Tab. 2), spanning the period 9840 cal yr BP (calculated age for the lowermost sample at $88 \mathrm{~cm}$ ) to the present. After testing other age models, the data were best represented using a 0.3 smoothing spline (Fig. 2). Using this technique, the lowest accumulation rate is at $63 \mathrm{~cm}(203 \mathrm{yr} / \mathrm{cm})$, while the highest accumulation rate is at present $(8 \mathrm{yr} / \mathrm{cm})$. Using interpolation, from the age-depth model the accumulation rate is 170 $\mathrm{yr} / \mathrm{cm}$ at $88-67 \mathrm{~cm}$ core depth, $197 \mathrm{yr} / \mathrm{cm}$ at $66-43 \mathrm{~cm}, 40 \mathrm{yr} / \mathrm{cm}$ at $42-40 \mathrm{~cm}, 52 \mathrm{yr} / \mathrm{cm}$ at $39-33 \mathrm{~cm}, 59 \mathrm{yr} / \mathrm{cm}$ at $32-19 \mathrm{~cm}$, and $11 \mathrm{yr} / \mathrm{cm}$ from $31 \mathrm{~cm}$ to the surface. Median probability was calculated using Calib 7.1 (Tab. 2).

Loss-on-ignition analysis demonstrated that the sediment is organic, defined as having more than $12 \%$ organic carbon. Organic content is lowest in the bottom part of the core, $\sim 30 \%$ at $88-60 \mathrm{~cm}$ depth, and at $60-0 \mathrm{~cm}$ the average for organic matter is $\sim 38 \%$. 
Table 1. Stratigraphy of the Vale das Antas core

\begin{tabular}{l|l}
\hline \hline Depth $(\mathrm{cm})$ & \multicolumn{1}{c}{ Description } \\
\hline $0-20$ & Black organic material, rather compact and strongly decomposed, some rootless, roots and plant remains \\
$20-41$ & Black organic material, compact and strongly decomposed, few root fragments \\
$41-61$ & Black organic material, compact and strongly decomposed, few plant remains, slightly silty \\
$61-84$ & Black organic material, compact and completely decomposed, fine sandy \\
$84-88$ & Black organic material, compact and completely decomposed, few small yellow rocks \\
$88-$ & Rocky subsurface \\
\hline
\end{tabular}

Table 2. AMS radiocarbon dates from the VAF core, with calibrated age ranges at $95 \%$ confidence intervals

\begin{tabular}{l|c|l|c|c|c}
\hline \hline Lab code & $\begin{array}{c}\text { Depth } \\
(\mathrm{cm})\end{array}$ & Material dated & $\begin{array}{c}\text { Date } \\
\left({ }^{14} \mathrm{C} \text { age BP }\right)\end{array}$ & $\begin{array}{c}\text { Calendar age } \\
(\text { cal yr BP }) \\
2 \sigma\end{array}$ & $\begin{array}{c}\text { Median } \\
\text { probability } \\
\text { (cal yr BP) }\end{array}$ \\
\hline Poz-106102 & 19 & Organic bulk sediment & $180 \pm 30$ & $\begin{array}{c}164-282(46.1 \%) \\
56-123(25 \%) \\
-3-33(13.4 \%) \\
132-157(10.1 \%) \\
39-40(0.3 \%)\end{array}$ & 152 \\
\hline Poz-106103 & 33 & Organic bulk sediment & $1115 \pm 30$ & $\begin{array}{c}927-996(68.5 \%) \\
1013-1056(26.4 \%)\end{array}$ & 969 \\
\hline Ntuams-2691 & 40 & Organic bulk sediment & $1511 \pm 9$ & $1315-1369(95 \%)$ & 1343 \\
\hline Poz-106105 & 43 & Organic bulk sediment & $1610 \pm 30$ & $\begin{array}{c}1400-1531(90.1 \%) \\
1378-1393(4.7 \%)\end{array}$ & 1461 \\
\hline Poz-106106 & 67 & Organic bulk sediment & $5460 \pm 110$ & $\begin{array}{c}5982-6406(92.2 \%) \\
5941-5974(2.8 \%)\end{array}$ & 6196 \\
\hline Ntuams-2015 & 86 & Organic bulk sediment & $8465 \pm 44$ & $\begin{array}{c}9396-9529(82.7 \%) \\
9308-9361(11.3 \%) \\
9375-9382(1 \%)\end{array}$ & 9455 \\
\hline
\end{tabular}

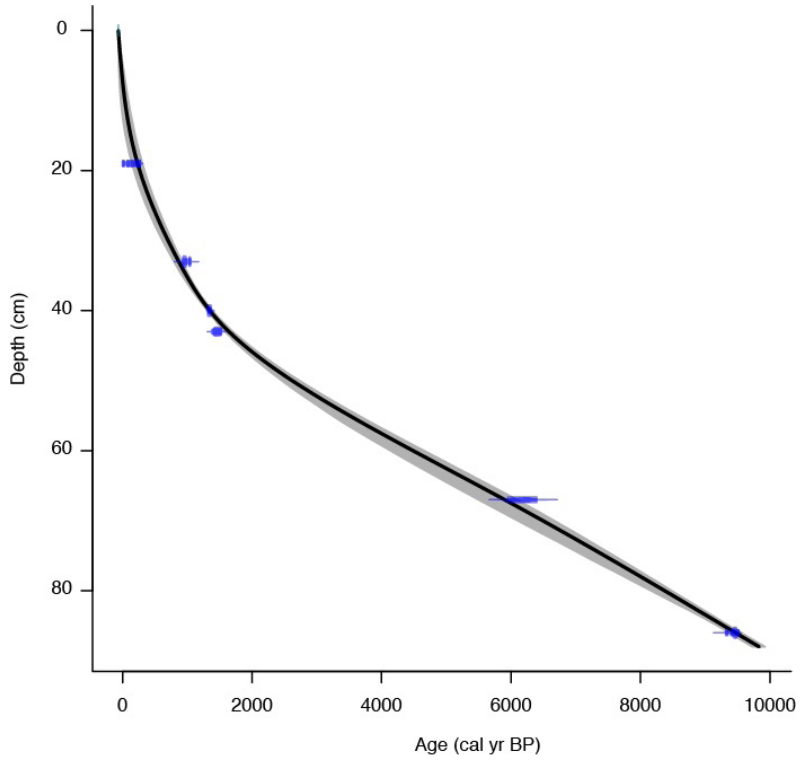

Fig. 2. Age-depth smoothing spline model for the Vale das Antas core

\section{PALYNOLOGICAL RESULTS}

The record is divided into three pollen zones based on constrained cluster analyses by CONISS: VAF-I, VAF-II and VAF-III. A total of 94 pollen and 37 spore taxa were identified in the 44 samples (supplementary material). 12 pollen types remain unidentified. The pollen percentage diagram (Fig. 3a) shows the dominant and most important taxa grouped into CDA, UMARF, OARF, LMARF and ferns. The summary diagram (Fig. 3b) shows the total percentage sum for each group: CDA, UMARF, OARF, LARF, tree ferns and spores, and the sum of all Asteraceae types. Figure $3 \mathrm{~b}$ also includes the depth curves of sedimentation rate $(\mathrm{yr} / \mathrm{cm})$, LOI $(\%)$, charcoal concentration (particles $\mathrm{cm}^{-3}$ ), charcoal accumulation rate (particles $\mathrm{cm}^{-2} \mathrm{yr}^{-1}$ ), fire peaks and fire magnitude.

$$
\begin{gathered}
\text { VAF-I (88-60 cm; 9840-4480 cal yr BP) } \\
14 \text { samples }
\end{gathered}
$$

This zone is characterized by the dominance of CDA pollen, averaging $61 \%$ and ranging from $49 \%$ to $69 \%$. Poaceae is the most dominant taxon $(46 \%,>32 \%$ to $<55 \%)$, followed by different Asteraceae types which represent almost $10 \%$ of the pollen sum in this zone $(>7.5 \%$ to $<12 \%$ ). However, Baccharis shows its lowest values in the core in this zone $(\sim 2 \%)$. Other taxa characteristic for the CDA assemblages in VAF-I are Apiaceae ( 2\%), Cyperaceae (1\%) and Fabaceae (1\%).

The average sum of arboreal taxa represents $33 \%$ (25-44\%) of the pollen spectra, and are dominated by UMARF, represented primarily by Weinmannia $(10 \%,>5 \%$ to $<17 \%)$ and Myrsine $(6 \%,>3 \%$ to <8\%). Most taxa of UMARF have their lowest values in this zone, 


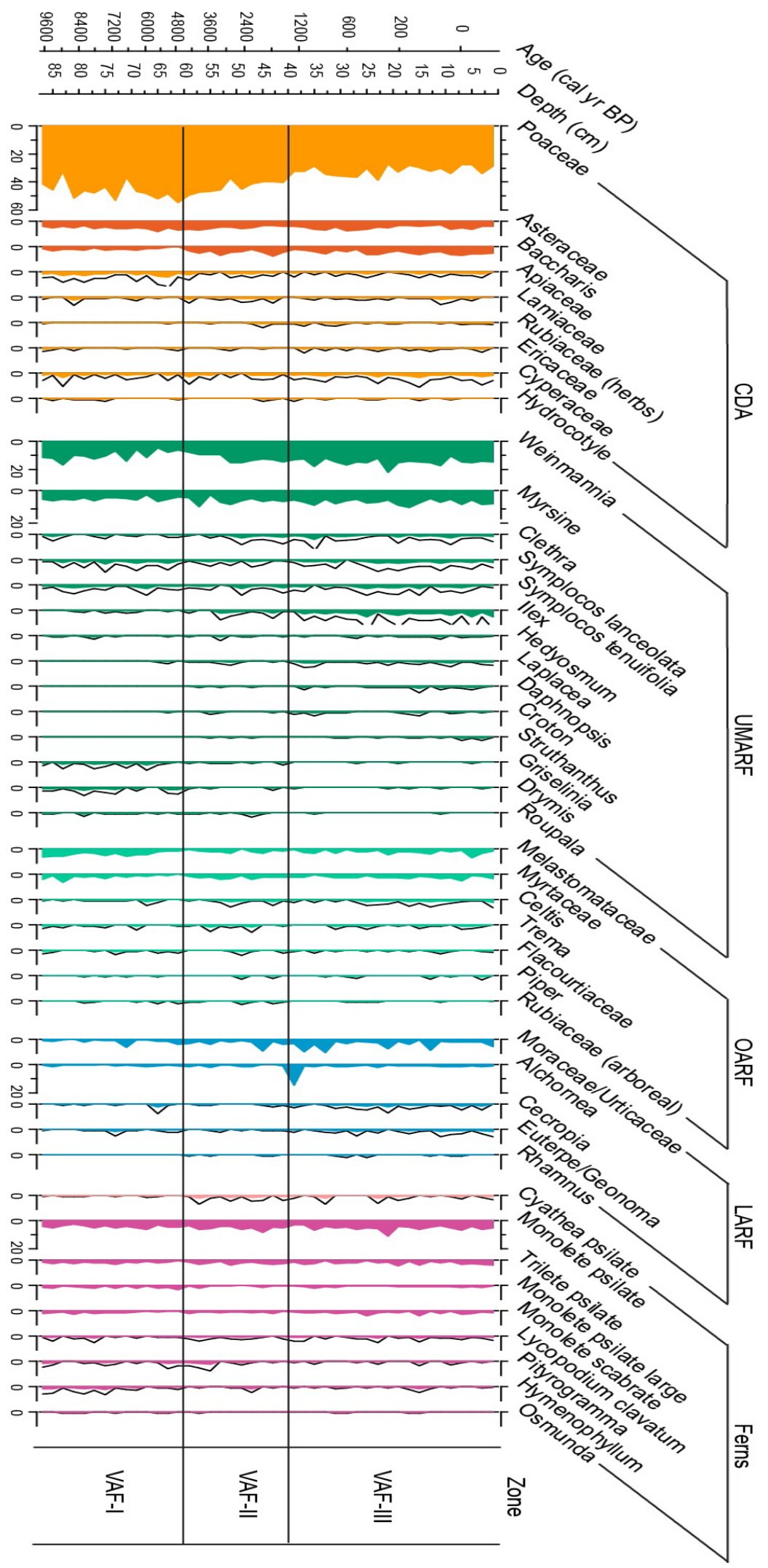

Fig. 3a. Pollen percentage diagram of the most important and most frequent taxa of the VAF core into each group 


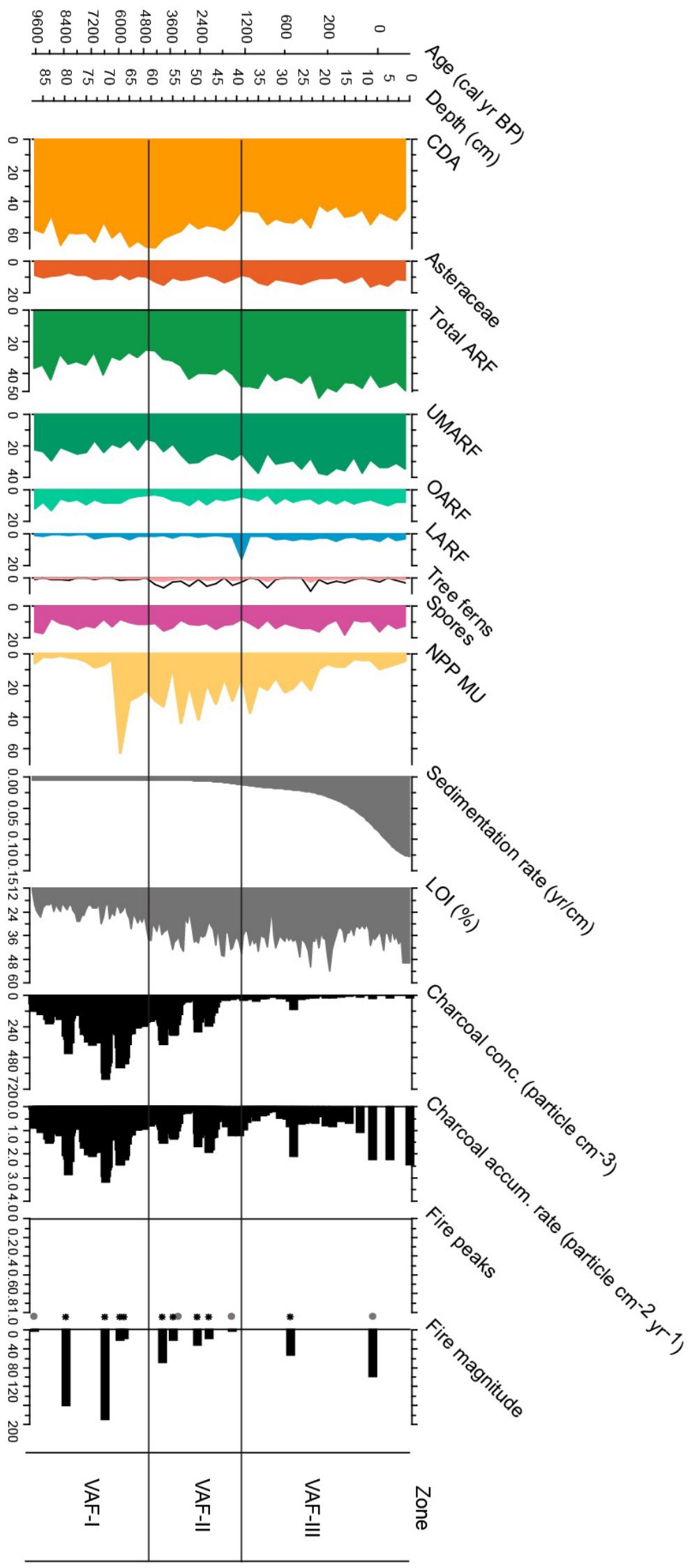

Fig. 3b. Summary diagram of the Vale das Antas Forest core, showing the ecological groups (\%), sedimentation rate (yr/cm), loss on ignition (\%), macro-charcoal concentration (particle $\mathrm{cm}^{-3}$ ) and accumulation rate (particle $\mathrm{cm}^{-2} \mathrm{yr}^{-1}$ ), fire peaks and fire magnitude. A $5 \times$ exaggeration scale line is shown for low percentage values 
but Griselinia and Drimys follow an opposite trend and are found at their highest densities in this zone, $\sim 1 \%$ each. In contrast to the UMARF group, OARF pollen shows its highest values in this zone, averaging $8 \%$ and ranging from $4 \%$ to $13 \%$, with Melastomataceae at $\sim 4 \%$ and Myrtaceae $\sim 2 \%$. LMARF pollen are scarce in VAF-I and average only $3 \%$ of the pollen sum, ranging from $1 \%$ to $8 \%$, represented primarily by Moraceae/Urticaceae (1.5\%) and Alchornea (1\%). Tree ferns occur only as a few single spores. Other fern spores show a roughly continuously percentage in the zone at $\sim 12 \%(>8 \%$ to $<17 \%)$.

\section{VAF-II (60-40 cm; 4480-1350 cal yr BP) 10 samples}

The CDA pollen percentages slightly decrease to $59 \%$, ranging from $\sim 70 \%$ at $50 \mathrm{~cm}$ to $54 \%$ at $41 \mathrm{~cm}$ core depth. Poaceae $(43 \%,>37 \%$ to $<49 \%)$ and Asteraceae types $(\sim 12 \%,>9 \%$ to $<15 \%$ ) continue as the main taxa, and Baccharis increases to $\sim 4 \%$. The arboreal assemblage reaches $\sim 37 \%$ (ranging from $26 \%$ to $44 \%$ ) mostly due to the UMARF group $(25 \%,>17 \%$ to $<31 \%$ ), characterized mainly by Weinmannia $(12 \%,>8 \%$ to $<15 \%)$ and Myrsine $(\sim 7 \%,>3 \%$ to $<11 \%)$. Clethra, Symplocos lanceolata, S. tenuifolia and Ilex represent $\sim 1 \%$ each. The OARF assemblage gradually decreases to $6.5 \%(>3 \%$ to $<10 \%$ ), with Melastomataceae pollen declining to less than $2 \%$ while Myrtaceae increases to $2.5 \%$. LMARF increases slightly to $4.5 \%$ $(>2 \%$ to $<10 \%)$ in VAF-II, driven primarily by Moraceae/Urticaceae which reaches almost 3\% $(>15 \%$ to $<8.5 \%)$. Relatively speaking, tree fern pollen increases greatly in this zone but only to $\sim 1 \%$, while other fern spores are stable at $12 \%$ $(>9 \%$ to $<16 \%)$.

\section{VAF-III ( $40-0 \mathrm{~cm} ; 1350 \mathrm{cal}$ yr BP to present) 20 samples}

In this zone, CDA pollen show a noticeable decrease to $49 \%$ (ranging from $42 \%$ to $57 \%$ ) of the pollen sum. This is driven primarily by the decrease of Poaceae to $32 \%$ ( $>27 \%$ to $<39 \%$ ). Asteraceae oscillates but on average maintains the same sum as VAF-II $(12 \%,>9 \%$ to $<16 \%)$, while Cyperaceae reaches its maximum average value of $1.5 \%$. Arboreal pollen increases to $\sim 47 \%$ (39-56\%), led by UMARF pollen at $32 \%$ $(>25 \%$ to $<38 \%)$ and LMARF pollen at $7.5 \%$. Although Weinmannia and Myrsine remain the most important taxa in the UMARF group, increasing to $15 \%(>11 \%$ to $<22 \%)$ and $\sim 8 \%$ $(>6 \%$ to $<12 \%)$ respectively, other taxa also contribute to the increase in VAF-III. Clethra, S. lanceolata and S. tenuifolia occur at $\sim 1 \%$ each and Ilex reaches $\sim 2 \%$. OARF continues with $\sim 7 \%$ (ranging from $3 \%$ to $10 \%$ ), and its main taxa (Melastomataceae and Myrtaceae) remain constant. A stronger change is observed in LMARF, which reaches its maximum (mean $=7.5 \%, 3-20 \%)$, due to the expansion of Moraceae/Urticaceae (3.7\%), Alchornea (2\%,) Cecropia (1\%) and Euterpe/Geonoma (0.7\%). As in the previous zones, non-tree fern spores are at $12 \%(>8.5 \%$ to $<16 \%)$, while tree ferns show slightly reduced values.

\section{MACRO-CHARCOAL AND FIRE REGIME}

CharAnalysis of macro-charcoal characterized the fire history for the past 9840 years (Fig. 3b). Average concentration for the entire sediment is 190 particles $\mathrm{cm}^{-3}$, decreasing from 250 particles $\mathrm{cm}^{-3}$ in zone VAF-I to 150 particles $\mathrm{cm}^{-3}$ in VAF-II and only 30 particles $\mathrm{cm}^{-3}$ in zone VAF-III. Local signal-to-noise exceeds 3.5, indicating good separation between peak and non-peak values. Of 13 fire peaks, 4 fire episodes failed to pass the Poisson minimumcount criterion, including the most recent peak at $9 \mathrm{~cm}$ depth (19 cal yr BP). The most recent significant peak is at $28 \mathrm{~cm}$ depth, (565 cal yr BP). The mean fire return interval (FRI, 95\% probability), calculated with a $1000-\mathrm{yr}$ window and only using fires that met the minimumcount criterion, is 998 yr (593-1449 yr). Using all 13 identified fire peaks and calculating the FRI across the entire record yields an FRI of 617 (446-827 yr). Under either measure, local fire events (fires within $\sim 500 \mathrm{~m}$ of the core site) were rare over the period of our sample, but the nearly continuous presence of charcoal through the core demonstrates that fires were not uncommon regionally. Most fire peaks as well as the highest magnitude peaks occurred in zone VAF-I.

\section{INTERPRETATION AND DISCUSSION}

Overall, the stratigraphy and the organic matter content of the VAF core in Serra dos Órgãos National Park indicate that there was a change from drier to wetter climatic conditions in the region during the Holocene, demonstrated by the lower accumulation rate and 
lower organic matter in the bottom part of the core. From the beginning of the pollen record, the general study area was dominated by CDA, rich in grass and shrubs, represented mostly by species of Poaceae, Asteraceae, Apiaceae and Cyperaceae. Forest cover at high elevations $(>1800 \mathrm{~m})$ in the Serra dos Órgãos and other mountains in southeastern Brazil is extremely heterogeneous and controlled largely by climotopographic and soil variables in combination with disturbance (Safford, 1999a,b, 2001). Other studies of palaeovegetation in the southeastern Brazilian mountains (Behling, 1997b; Behling et al. 2007; Behling and Safford, 2010; Veríssimo et al., 2012; Behling et al., 2020) show a trend of increasing forest cover - and decreasing campos cover - at high elevations since the Early Holocene, with acceleration of this trend during the Late Holocene, indicating that the regional climate during the Early Holocene was much drier than today and that CDA vegetation was much more widespread than today.

Our pollen data suggest that UMARF was not widely distributed at higher elevations $(>1800 \mathrm{~m})$ in the Serra dos Órgãos in VAF-I (9840-4480 cal yr BP), and that the more continuous local forest may not have developed until after 1350 cal yr BP (VAF-III). Before 4480 cal yr BP the study site was rich in genera of southern temperate-latitude ancestry such as Weinmannia, Drimys and Griselinia, implying a somewhat colder climate than today. UMARF taxa of tropical origin were also represented in the Early Holocene pollen, but their abundances were mostly low or very low before they began to rise substantially after $4480 \mathrm{yr}$ cal BP. Examples of this pattern include Clethra, Ilex, Laplacea, Daphnopsis, Croton and the tree ferns. Some UMARF genera were already relatively common before 4480 cal yr BP but saw their abundances rise further thereafter. Examples are Weinmannia ( $2 \times$ increase) and Myrsine (50\% increase). Symplocos, Melastomataceae and Myrtaceae (the latter two very common in both UMARF and OARF) showed relatively invariant abundances throughout the Holocene. The modern UMARF is characterized by species of temperate, Neotropical and tropical origin which occur in the majority of UMARF in southeastern and southern Brazil (e.g. Portes et al., 2001; Safford, 2007; Scheer and Mocochinski, 2009; Gomes, 2015; Moreira et al., 2018).

Modern pollen rain data from the Serra dos Órgãos (Portes et al., 2020) suggest that areas of CDA are under-represented in the total pollen assemblage due to (1) the low pollen production and low accumulation rate of CDA taxa, and (2) the over-representation of some arboreal taxa, especially pioneer or secondary species of montane forest that are wind-transported over large areas and elevational ranges. Portes et al. (2020) proposed that a restricted group of typical upper montane forest taxa provides a more trustworthy measure of actual montane forest presence at a site than the full ARF group. Therefore, following Portes et al. (2020), we aggregated pollen sums from Weinmannia, Myrsine, Myrtaceae and Clethra to represent UMARF and we aggregated the same taxa used by Behling and Safford (2010) to represent the CDA. Figure 4 shows the temporal trends in this group of taxa and in CDA from our VAF core and the SDO core sampled by Behling and Safford (2010) (which stretched back into the Late Pleistocene, 12,380 cal yr $\mathrm{BP}$ ), and superimposes the macro-charcoal concentration (particles $\mathrm{cm}^{-3}$ ) from the VAF core and the $\delta^{18} \mathrm{O}$ record from Bernal et al. (2016). Our data suggest that the study site was dominated by CDA vegetation for most of the Holocene, with more or less uniform CDA vegetation in the Early Holocene and a notable contraction in the Late Holocene after 4500 yr BP (but apparently occurring earlier at the SDO core site), corroborating the higher charcoal concentration as well as the drier climate at that period. As the climate becomes wetter after $\sim 1400$ cal yr BP, the charcoal concentration decreases, the CDA:forest (sum of ARF subdivisions) ratio drops to 50:50, and the group of upper montane ARF increases to $\sim 30 \%$. The SDO core shows similar patterns, with an accentuated increase in forest pollen after $\sim 5000 \mathrm{cal}$ yr BP and the balance of campos vs. forest pollen dropping below 50:50 after $\sim 1500$ cal yr BP (Fig. 4). While the VAF core was collected in a currently UMARF patch surrounded by CDA vegetation, the SDO core was cored from more widespread CDA vegetation. We hypothesize therefore that the patch of forest that currently occupies the VAF site has been extant only since sometime in the Late Holocene, although the pollen data make it clear that upper montane forest taxa have been in the broader region throughout the Holocene.

The VAF core also documents temporal floristic variation that points to important 


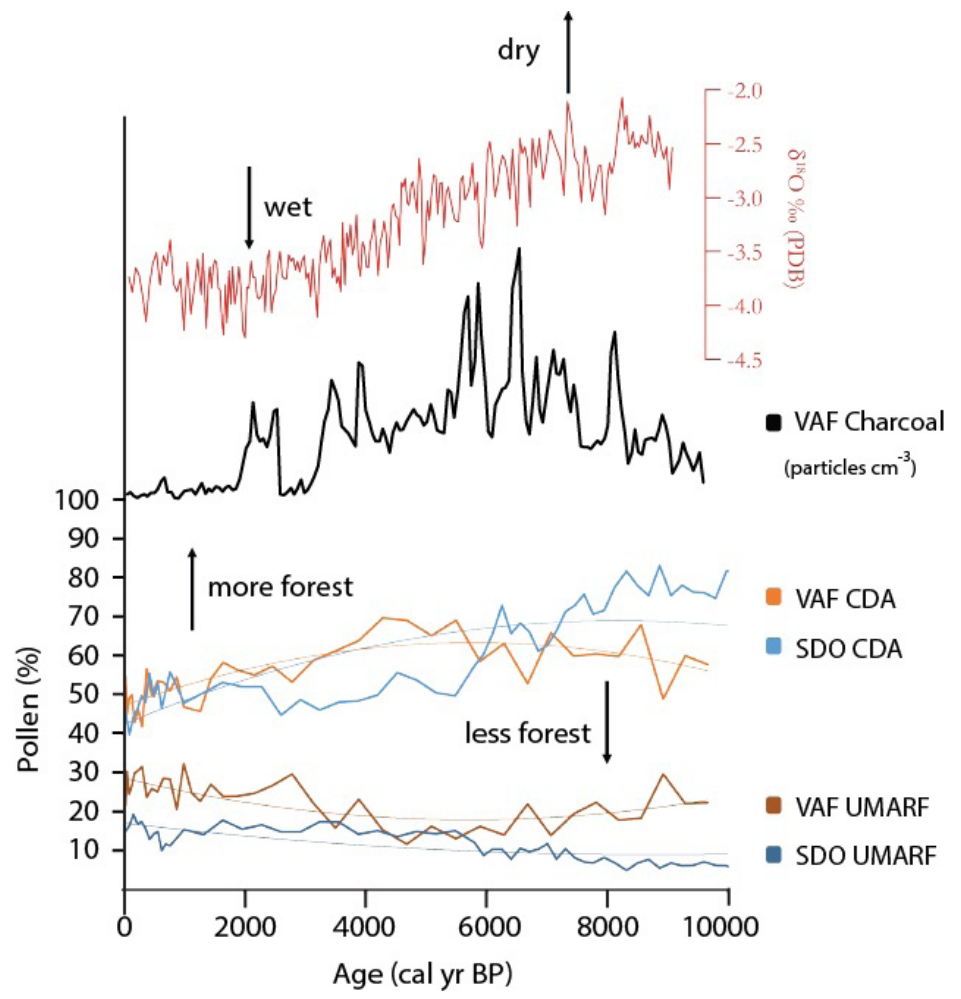

Fig. 4. Comparison of the sum (\%) of Weinmannia, Myrsine, Myrtaceae and Clethra taxa representing UMARF from the VAF core (VAF UMARF), the sum of Weinmannia, Myrsine, Myrtaceae and Clethra taxa representing UMARF from the SDO core (SDO UMARF), the sum of the CDA group from the VAF core (VAF CDA) and the sum of the CDA group from the SDO core (SDO CDA), plotted with macro-charcoal concentration (particles $\mathrm{cm}^{-3}$ ) from the VAF core and the $\delta^{18} \mathrm{O}$ record from Botuverá Cave (Bernal et al., 2016) for the last 10,000 years. Trendline from 2nd-order polynomial

changes in climate over the course of the Holocene. We interpret the Early and Mid-Holocene as relatively cool and dry (but becoming gradually warmer and wetter over time), based on (1) the general lack of tree ferns, (2) low LOI values, (3) relatively high frequency and magnitude of fire, (4) relatively low pollen density for Baccharis, which is a reliable campos indicator but under warmer temperatures, and (5) the elevated presence of cool climate indicators of southern temperate ancestry such as Drimys and Griselinia. In addition, the nearby SDO core records Araucaria pollen until $\sim 10,800$ cal yr BP, further pointing to cooler Early Holocene temperatures. UMARF vegetation in the Early and Mid-Holocene seems to have included a more substantial component of southern-temperate taxa than it does today.

Zones VAF-II (4480-1350 cal yr BP) and VAF-III (1350 cal yr BP to present) represent the Late Holocene. After 4480 cal yr BP the organic matter in the soil increased in tandem with increases in the abundance of UMARF and OARF taxa. Taxa of tropical origin such as Clethra, Symplocos, Celtis, Trema and Flacourtiaceae expanded, as did the tree ferns. Associated with the rising elevation and expansion of forest, fire magnitude and frequency declined, suggesting a shift to wetter conditions. A shift to even wetter conditions appears to have occurred at the beginning of VAF-III $(\sim 1350$ cal yr BP), demonstrated by a strong and abrupt intensification of sediment accumulation, a decrease in charcoal concentration, and a reduction of CDA pollen to $\sim 50 \%$ of the total. The sharp peak of Alchornea just after 1350 cal yr BP and the increase in other tropical LARF taxa (Moraceae/Urticaceae, Cecropia, and Euterpe/Geonoma type) are indicative of a rapid change toward a warmer and wetter climate in the Late Holocene. Since about 1200 cal yr BP the CDA/UMARF relationship has remained in an approximate balance in the study area. During this period, the last significant fire peak occurred at $\sim 600 \mathrm{cal} \mathrm{yr} \mathrm{BP,}$ possibly related to the VAF-III peak in CDA pollen and concurrent drop in UMARF pollen that occurred shortly thereafter.

Other studies also suggest an intensification in Late Holocene precipitation. Moss spores in the nearby SDO core increased greatly in Late Holocene sediment (Behling and Safford, 2010). Palaeoclimate data from the last 10,000 years at Botuverá Cave $\left(27^{\circ} 13^{\prime} \mathrm{S}, 49^{\circ} 09^{\prime} \mathrm{W}\right.$, 
$230 \mathrm{~m}$ a.s.l.; Bernal et al., 2016) registered an increase in rainfall starting about 4000 years ago (see Fig. 4), which coincides with the spread of forest vegetation and the declining occurrence and magnitude of fire in our core. Evidence for a relatively sudden increase in precipitation in VAF (see above) at around 1350 cal yr BP is also supported by studies of the SAMS (South American Monsoon System) over the last 2000 years, which show a strengthening monsoon during the Little Ice Age (LIA), resulting in a wetter period from $\sim 1400$ to 1800 AD (Vuille et al., 2012).

Charcoal in the VAF and SDO cores suggests that fires have occurred in the Serra dos Órgãos since at least the Late Pleistocene, that is, before the documented arrival of humans in southeastern Brazil around 10,000 years ago (Figuti et al., 2004). Longer records from other CDA sites in the southeastern Brazilian mountains show notably more fire even further back in time, such as the 35,000-year record from Morro do Itapeva in the southern Serra da Mantiqueira (Behling, 1997b) and the 18,600-year record from the Serra da Bocaina (Behling et al., 2007). However, fires in the immediate locality of the VAF core were infrequent during the Holocene. By using relatively large macro-charcoal $(>150 \mu \mathrm{m})$ in our CharAnalysis, we restricted our assessment to fires that probably occurred within $500 \mathrm{~m}$ or so of the core site (Higuera et al., 2007). This permits a more site-specific understanding of the fire history and suggests that the Holocene fire return interval in this wet but seasonally dry landscape was long, ranging from around 600 to 1000 years (depending on our assumptions). It is also clear, however, that fires were, and usually still are, relatively small, and our analysis thus under-represents the fire regime of the broader landscape. Topographically the Serra dos Órgãos landscape is extremely abrupt and heterogeneous (the rise from Guapimirim to Pedra do Sino is $2210 \mathrm{~m}$ in less than $8 \mathrm{~km}$, and some of the tallest rock walls in all of Brazil are found here), and the high mountain summits and plateau that support CDA are small, ringed by cliffs and humid forest, and cut by deep gorges (see Fig. 1). As a result, lightning ignitions that occur on topographic eminences with combustible fuels (graminoids or dry woody fuels) have little chance to spread far. Most lightning strikes in southeastern Brazil occur during the wet season, but lightning at either the beginning or end of the wet season has the potential to cause fire (Safford, 2001). Today most ignitions are anthropogenic and occur during the dry season, when lightning ignitions are far more rare. Human-caused ignitions that occur during very warm and especially windy conditions can spread from mountain to mountain and even burn appreciable areas of forest. Control of such fires is a major conservation issue in the Brazilian National Park system.

Another reason our charcoal analyses almost certainly under-represent palaeofire frequency in the CDA is that macro-charcoal $(>150 \mu \mathrm{m})$ is composed of charred woody fragments, but graminoids are the principal fuel for fire in the campos. Whitlock et al. (2004) noted that the best correspondence between real fire frequency and charcoal records is where woody vegetation is dense and continuous, a condition that is rare at the highest elevations of the Serra do Mar. Behling et al. (2020) found a similar site-specific fire return interval for the AN core from the Serra do Itatiaia (mean $=630$ years through the Mid- and Late Holocene) and noted similar issues with the dominance of graminoid vegetation in the surrounding landscape. Obvious directions for further research are (1) to conduct macro-charcoal analyses of already published cores that predated the development of the analytical techniques (such cores exist from a number of high montane sites in southeast Brazil), (2) to obtain sediment core samples from more - and both elevationally and vegetationally more varied - locations in the southeastern Brazilian highlands, and (3) to develop new techniques to better assess fire frequencies and magnitudes using charcoal from herbaceous sources.

\section{SUMMARY AND CONCLUSION}

Like other studies of palaeovegetation in the southeastern Brazilian mountains (Behling and Safford, 2010; Behling et al., 2007; ScheelYbert, 2001; Veríssimo et al. 2012), the VAF record shows a clear trend from drier to wetter climatic conditions during the Holocene, and a clear trend of replacement of CDA vegetation by forest vegetation. The results indicate that the higher elevations of Serra dos Órgãos have been occupied by a mosaic of CDA and UMARF since the beginning of the record 
(9840 cal yr BP), although the forest patch that occupies the VAF site probably has been extant only since $\sim 1350$ cal yr BP.

Both the VAF record (collected in a forest patch) and SDO record (cored in CDA vegetation) indicate that CDA was much more widespread in the Late Holocene than it is today, and both core sites also demonstrate a similar pattern of forest moving consistently upwards through much of the Holocene. This is especially the case for UMARF taxa but also for montane ARF. At around 1000 cal yr BP (1350 cal yr BP in VAF and 880 cal yr BP in SDO) the data indicate a marked shift toward a warmer and wetter climate, further favouring the expansion of forest vegetation. The variability in the timing of these climatic events between the two cores is likely related to differences in vegetation and relief as well as the error intrinsic to ${ }^{14} \mathrm{C}$ dating.

The macro-charcoal record in the VAF core corroborates changes seen in climate and vegetation. Fires were more frequent and of greater magnitude in the Early Holocene, decreased after $\sim 4000 \mathrm{cal} \mathrm{yr} \mathrm{BP}$, and have been very rare in the Late Holocene. The nearby SDO core (Behling and Safford, 2010) showed similar patterns, with more frequent fire during the Early Holocene, especially from 10,800 to 7850 cal yr BP, and a decreasing trend until $\sim 5640$ cal yr BP, when charcoal concentrations and accumulation more or less levelled off.

Our results support the conclusions of previous studies (e.g., Behling, 1997b; Safford, 2001; Behling et al., 2007; Behling and Safford, 2010; Veríssimo et al., 2012) that fire has long been a natural disturbance factor in the campos de altitude. Nevertheless, before the arrival of humans at these mountain sites, fires mostly occurred during the wet season, and today anthropogenic ignitions occur primarily during the dry season in very warm and windy conditions; the fires can be enormous. Further research is needed to better define the natural fire regime in the Brazilian Highlands. Another conservation concern is the long-term increase in precipitation and temperature that has been underway for centuries and is rapidly accelerating as greenhouse gas emissions rise. Forest expansion into previously grasslanddominated sites threatens the habitat heterogeneity that underlies the high biodiversity and endemism of these montane sites (Safford, 2001; Portes et al., 2018). We recommend that protected areas containing campos de altitude and upper montane rain forest should develop management strategies that incorporate observation, measurement, experimentation, and active management techniques that help to retain landscape heterogeneity (see Portes et al., 2018). The standard "hands-off" protectionism that has characterized national park management for the last century may be particularly poorly suited to conservation in an age of rapid global change (Cole and Yung, 2010; Safford et al., 2012).

\section{ACKNOWLEDGEMENTS}

We are grateful to the Instituto Chico Mendes de Conservação da Biodiversidade (ICMBio), the original institution of the first author, for granting permission to develop this research in the PARNASO. We also thank Cecilia Cronemberger from PARNASO and José Guilherme Carvalho da Costa for helping in the fieldwork, and Dr. Vera Markgraf and one anonymous reviewer for their important reviews. This work was supported by the Ciências sem Fronteiras/CNPq program, Brazil (grant $\mathrm{n}^{\circ}$ 232876/2014-2 to the first author).

\section{REFERENCES}

Barnosky, A.D., Hadly, E.A., Gonzalez, P., Head, J., Polly., P.D., Lawing, A.M. et al., 2017. Merging paleobiology with conservation biology to guide the future of terrestrial ecosystems. Science 355, issue 6325; DOI: 10.1126/science.aah4787.

Behling, H., 1993. Untersuchungen zur Spätpleistozänen und Holozänen Vegetations- und Klimageschichte der Tropischen Küstenwälder und der Araukarienwälder in Santa Catarina (Südbrasilien). (PhD thesis). J. Cramer, Berlin, Stuttgart.

Behling, H., 1995. Investigations into the Late Pleistocene and Holocene history of the vegetation and climate in Santa Catarina (S Brazil). Vegetation History and Archaeobotany 4, 127-152.

Behling, H., 1997a. Late Quaternary vegetation, climate and fire history of the Araucaria forest and campos region from Serra Campos Gerais, Paraná State (South Brazil). Review of Palaeobotany and Palynology 97, 109-121.

Behling, H., 1997b. Late Quaternary vegetation, climate and fire history from the tropical mountain region of Morro de Itapeva, SE Brazil. Palaeo 129, 407-422.

Behling, H., 2007. Late Quaternary vegetation, fire and climate dynamics of Serra do Araçatuba in the Atlantic coastal mountains of Paraná State, southern Brazil. Vegetation History and Archaeobotany 16, 77-85.

Behling, H., Pillar, V.D., 2007. Late Quaternary vegetation, biodiversity and fire dynamics on the 
southern Brazilian highland and their implication for conservation and management of modern Araucaria forest and grassland ecosystems. Philosophical Transactions of the Royal Society B: Biological Sciences 362, 243-251.

Behling, H., Safford, H.D., 2010. Late-glacial and Holocene vegetation, climate and fire dynamics in the Serra dos Órgãos, Rio de Janeiro State, southeastern Brazil. Global Change Biology 16, 1661-1671.

Behling, H., Dupont, L., Safford, H.D., Wefer, G., 2007. Late Quaternary vegetation and climate dynamics in the Serra da Bocaina, southeastern Brazil. Quaternary International 161, 22-31.

Behling, H., Jantz, N., Safford, H.D., 2020. Mid- and late Holocene vegetation, climate and fire dynamics in the Serra do Itatiaia, Rio de Janeiro State, southeastern Brazil. Review of Palaeobotany and Palynology 274, 104-152.

Bernal, J.P., Cruz, F.W., Stríkis, N.M., Wang, X., Deininger, M., Catunda, M.C.A., Ortega-Obregón, C., Cheng, H., Edwards, R.L., Auler, A.S., 2016. Highresolution Holocene South American monsoon history recorded by a speleothem from Botuverá Cave, Brazil. Earth and Planetary Science Letters 450, 186-196.

Biagioni, S., Krashevska, V., Achnopha, Y., Saad, A., Sabiham, S., Behling, H., 2015., 8000 years of vegetation dynamics and environmental changes of a unique inland peat ecosystem of the Jambi Province in Central Sumatra, Indonesia. Palaeogeography, Palaeoclimatology, Palaeoecology 440, 813-829.

Blaauw, M., 2010. Methods and code for 'classical' agemodelling of radiocarbon sequences. Quaternary Geochronology 5, 512-18.

Câmara, I.G., 2003. Brief history of conservation in the Atlantic Forest. In: Galindo-Leal, C., Câmara, I.G. (eds), The Atlantic Forest of South America: Biodiversity Status, Threats, and Outlook. CABS and Island Press, Washington, pp. 31-42.

Cole, D.N., Yung, L., eds, 2010. Beyond naturalness: Rethinking park and wilderness stewardship in an era of rapid change. Island Press, Washington, DC, USA.

Dean, W., 1995. With Broadax and Firebrand: The destruction of the Brazilian Atlantic Forest. University of California Press, Berkeley.

Faegri, K., Iversen, J., 1989. Textbook of modern pollen analysis. 4th ed. John Wiley and Sons, Chichester.

Falkenberg, D.B., Voltolini, J.C., 1995. The Montane Cloud Forest in Southern Brazil. In: Hamilton, L.S., Juvik, J.O., Scatena, F.N. (eds) Tropical Montane Cloud Forests. Ecological Studies 110, New York: Springer-Verlag, pp. 138-149.

Figuti, L., Eggers, S., Mendonça, C.A., Porsani, J.L., Rocha, E.B., De Blasis, P.A.D., Bissa, W.M., 2004. Investigações arqueológicas e geofísicas dos sambaquis fluviais do vale do Ribeira de Iguape, Estado de São Paulo. Museu de Arqueologia e Etnologia,
USP. Relatório Final de Atividades de Projeto Temático, processo FAPESP n 1999/12684-2, período: 6/2003 a 4/2004.

Flora do Brasil, 2020. Jardim Botânico do Rio de Janeiro. Available at: http://floradobrasil.jbrj.gov.br/

Fundação SOS Mata Atlântica/ INPE - Instituto Nacional de Pesquisas Espaciais, 2017. Atlas dos remanescentes florestais da Mata Atlântica - período 2015-2016. Relatório técnico. São Paulo.

Gomes, C.G., 2015. Composição florística e estrutural do componente arbóreo de um fragmento de mata nebular no Parque Nacional da Serra dos Órgãos, Rio de Janeiro, Brasil. Graduate dissertation, unpublished.

Grimm, E.C., 1987. CONISS: a FORTRAN 77 program for stratigraphically constrained cluster analysis by the method of incremental sum of squares. Computers and Geosciences 13, 13-35.

Heiri, O., Lotter, A.F., Lemcke, G., 2001. Loss on ignition as a method for estimating organic and carbonate content in sediments: reproducibility and comparability of results. Journal of Paleolimnology 25, 101-110.

Higuera, P., 2009. CharAnalysis 0.9: diagnostic and analytical tools for sediment-charcoal analysis. User's guide. Montana State University. http:// CharAnalysis.googlepages.com.

Higuera, P.E., Peters, M.E., Brubaker, L.B., Gavin, D.G., 2007. Understanding the origin and analysis of sediment-charcoal records with a simulation model. Quaternary Science Reviews 26, 1790-1809.

Higuera, P.E., Gavin, D.G., Bartlein, P.J., Hallet, D.J., 2010. Peak detection in sediment-charcoal records: impacts of alternative data analysis methods on fire-history interpretations. International Journal of Wildland Fire 19, 996-1014.

Hijmans, R.J., Cameron, S.E., Parra, J.L., Jones, P.G., Jarvis, A., 2005. Very high resolution interpolated climate surfaces for global land areas. International Journal of Climatology 25, 1965-1978. WorldClim - Global Climate Data, extracted in 8/05/2019.

Hueck, K., 1966. Die Wälder Südamerikas. Ökologie, Zusammensetzung und wirtschaftliche Bedeutung. Gustav Fischer Verlag, Stuttgart.

ICMBio - Instituto Chico Mendes de Conservação da Biodiversidade, 2008. Plano de Manejo do Parque Nacional da Serra dos Órgãos. Available at http:// www.icmbio.gov.br/portal/component/content/ article?id=2196:parna-da-serra-dos-orgaos.

ICMBio - Instituto Chico Mendes de Conservação da Biodiversidade, 2018. Livro vermelho da fauna brasileira ameaçada de extinção, vol. I. 1 ed. ICMBio/ MMA, Brasilia, DF. 492 p. (available at https:// www.icmbio.gov.br/portal/component/content/article/10187).

Juggins, S., 2007. C2 User Guide: Software for Ecological and Palaeoecological Data Analysis and Visualization. University of Newcastle, Newcastle upon Tyne, UK, pp. 1-73. 
Ledru, M.P., Rousseau, D.D., Cruz Jr., F.W., Riccomini, C., Karmann, I., Martin, L., 2005. Paleoclimate changes during the last 100,000 yr from a record in the Brazilian Atlantic rainforest region and interhemispheric comparison. Quaternary research 64, 444-450.

Ledru, M.P., Mourguiart, P., Riccomini, C., 2009. Related changes in biodiversity, insolation and climate in the Atlantic rainforest since the last interglacial. Palaeoeography, Palaeoclimatology, Palaeoecology 271, 140-152.

Martinelli, G., Bandeira, J., 1989. Campos de altitude. Editora Index, Rio de Janeiro.

Martinelli, G., Moraes, M.A. 2013. Livro vermelho da flora do Basil. 1. ed. Instituto de Pesquisas Jardim Botânico do Rio de Janeiro. Rio de Janeiro. 1100 p. (available at https://dados.gov.br/dataset/ portaria_443).

Melhem, T.S., Cruz-Barros, M.A.V, Côrrea, A.M.S., Makino-Watanabe, H., Silvestre-Capellato, M.S.F., Esteves, V.L.G., 2003. Variabilidade Polínica em Plantas de Campos do Jordão (São Paulo, Brasil). Boletim do Instituto de Botânica de São Paulo, São Paulo.

Moreira, B., Carvalho, F.A., Menini Neto, L., Salimena, F.R.G., 2018. Phanerogamic flora and phytogeography of the Cloud Dwarf Forests of Ibitipoca State Park, Minas Gerais, Brazil. Biota Neotropica 18(2).

Myers, N., Mittermeier, R.A., Mittermeier, C.G., Fonseca, G.A.B., Kent, J., 2000. Biodiversity hotspots for conservation priorities. Nature 403, 853-858.

Nimer, E., 1977. Clima. In: IBGE - Instituto Brasileiro de Geografia e Estatística. geografia do Brasil: região sudeste, vol. 3. SERGRAF - IBGE, Rio de janeiro, pp. 51-90.

Noelli, F.S., 2008. The Tupi expansion. In: H., Silverman, W.H., Isbell (eds), Handbook of South American Archaeology, Springer, New York, Chapter 33, pp. 659-670.

Overbeck, G.E., Vélez-Martin, E., Scarano, F.R., Lewinsohn, T.M., Fonseca, C.R., Meyer, S.T., Müller, S.C., Ceotto, P., Dadalt, L., Durigan, G., Ganade, G., 2015. Conservation in Brazil needs to include non-forest ecosystems. Diversity and Distributions 21(12), 1455-1460.

Portes, M.C.G.O., Galvão, F., Koehler, A., 2001. Caracterização florística e estrutural de uma Floresta Ombrófila Densa Altomontana do morro Anhangava, Quatro Barras, PR. Revista Floresta 31(1/2), 22-31.

Portes, M.C.G.O., Safford, H, Behling, H., 2018. Humans and climate as designers of the landscape in Serra da Bocaina National Park, southeastern Brazil, over the last seven centuries. Anthropocene $24,61-71$.

Portes, M.C.G.O., Safford, H., Montade, V., Behling, H., 2020. Pollen rain-vegetation relationship along an elevational gradient in the Serra dos Órgãos National Park, southeastern Brazil. Review of
Palaeobotany and Palynology 283, https://doi. org/10.1016/j.revpalbo.2020.104314

Raczka, M.F., de Oliveira, P.E., Bush, M., McMichael, C.H., 2013. Two paleoecological histories spanning the period of human settlement in southeastern Brazil. Journal od Quaternary Science 28, 144-151.

Ribeiro, M.C., Metzger, J.P., Martensen, A.C., Ponzoni, F.J., Hirota, M, M., 2009. The Brazilian Atlantic Forest: How much is left, and how is the remaining forest distributed? Implications for conservation. Biological Conservation 142, 1141-1153.

Riccomini, C., Peloggia, A.U., Saloni, J.C.L., Kohnke, M.W., Figueira, R.M., 1989. Neotectonic activity in the Serra do Mar rift system (southeastern Brazil). Journal of South American Earth Science 2, 191-198.

Rhodes, A.N., 1998. A Method for the Preparation and Quantification of Microscopic Charcoal from Terrestrial and Lacustrine Sediment Cores. The Holocene 8(1), 113-17.

Rull, V., Vegas-Vilarrúbia, T., Nogué, S., Huber, O., 2009. Conservation of the unique neotropical vascular flora of the Guyana Highlands in the face of global warming. Conservation Biology 23, 1323e1327.

R-Studio Team, 2016. RStudio: Integrated Development for R. RStudio, Inc., Boston, MA url: http:// www.rstudio.com/.

Safford, H.D., 1999a. Brazilian Páramos I. An introduction to the physical environment and vegetation of the campos de altitude. Journal of Biogeography $26,693-712$.

Safford, H.D., 1999b. Brazilian Páramos II. Macroand mesoclimate of the campos de altitude and affinities with high mountain climates of the tropical Andes and Costa Rica. Journal of Biogeography 26, 713-737.

Safford, H.D., 2001. Brazilian Páramos III. Patterns and rates of postfire regeneration in the campos de altitude. Biotropica 33(2), 282-302.

Safford, H.D., 2007. Brazilian Páramos IV. Phytogeography of the campos de altitude. Journal of Biogeography 34, 1701-1722.

Safford, H.D., Hayward, G., Heller, N., Wiens, J.A., 2012. Climate change and historical ecology: can the past still inform the future? In: J.A., Wiens, G., Hayward, H.D., Safford, C.M., Giffen (eds). Historical environmental variation in conservation and natural resource management. John Wiley and Sons, New York, NY, pp. 46-62.

Scheel-Ybert, R., 2001. Man and Vegetation in Southeastern Brazil during the Late Holocene. Journal of Archaeological Science 28, 471-480.

Scheer, M.B., Mocochinski, A.Y., 2009. Florística vascular da Floresta Ombrófila Densa Altomontana de quarto serras no Paraná. Biota Neotropica 9(2), 51-69.

Stevenson, J., Haberle, S., 2005. Macro Charcoal Analysis: a modified technique used by the department of Archaeology and Natural History. Palaeoworks 
Technical Papers 5, p. 7. Department of Archaeology and Natural History, Research School of Pacific and Asian Studies, coombs Building, Australian National University, ACT 0200, Australia.

Stockmarr, J., 1971. Tablets with Spores used in Absolute Pollen Analysis. Pollen et Spores 13, 615-621.

Stuiver, M., Reimer, P.J., and Reimer, R.W., 2019. CALIB 7.1 at http://calib.org.

Vegas-Vilarrúbia, T., Rull, V., Montoya, E., Safont, E., 2011. Quaternary palaeoecology and nature conservation: a general review with examples from the neotropics. Quaternary Science Reviews 30, 2361-2388.
Veríssimo, P.N., Safford, H.D., Behling, H., 2012. Holocene vegetation and fire history of the Serra do Caparaó, SE Brazil. The Holocene 22, 1243-1250.

Vuille, M., Burns, S.J., Taylor, B.L., Cruz, F.W. Bird, B.W., Abbot, M.B., Kanner, L.C., Cheng, H., Novello, V.F., 2012. A review of the South American monsoon history as recorded in stable isotopic proxies over the pas t two millennia. Clim. Past. 8, 1309-1321.

Whitlock, C., Skinner, C.N., Bartlein, P.J., Minckley, T., Mohr, J.A., 2004. Comparison of charcoal and tree-ring records of recent fires in the eastern Klamath Mountains, California, USA. Canadian Journal of Forest Research 34, 2110-2121. 